\title{
Philosophical Interpretation of Cultural Confidence in Socialism with Chinese Characteristics in the New Era from the Perspective of Globalization
}

\author{
Hong Wang \\ Xi'an Medical University \\ Xi'an, China 710021
}

\begin{abstract}
With the enhancement of the strategic significance of culture in global communication, improving the national cultural soft power, mastering culture utterance right, and achieving the global allocation of cultural resources have become important concerns of the country's overall strategy. In the "Communist Manifesto", Marx and Engels first discussed the idea of economic globalization at the basic level, and then extended it to the globalization of spiritual production (culture). Today the trend of cultural globalization has become a reality, which is a double-edged sword for national culture. At present, China is in a new period of deepening the reform of the cultural system, and it is also a critical period of strategy for promoting the great development and prosperity of Chinese culture. Based on the "Communist Manifesto", a classic work of Marxist philosophy, this article expounds the cultural globalization thoughts in this work, which has important practical significance for strengthening the cultural confidence in socialism with Chinese characteristics in the new era.
\end{abstract}

Keywords-cultural confidence; cultural security; Communist Manifesto

\section{INTRODUCTION}

The report of the 19th National Congress of the Communist Party of China stated that "cultural confidence is a more basic, deeper, and lasting force in the development of a country and a nation" [1]. With the continuous improvement of the strategic significance of culture in global communication, improving the country's cultural soft power, mastering the right to speak culturally, and realizing the global allocation of cultural resources have naturally become important concerns of the country's overall strategy. Among them, cultural confidence is a major theoretical and practical issue related to the rise and fall of the national movement, cultural security, and national spiritual independence. "Without a high degree of cultural confidence and cultural prosperity, there will be no great rejuvenation of the Chinese nation" [2]. In the historical dimension of the new era, a firm cultural confidence is not only an important ideological engine for building up the Chinese spirit, Chinese values, and Chinese power, but also a powerful spiritual force for realizing the Chinese dream of the great revival of the Chinese nation. This article will understand and interpret the confidence of the socialist culture with Chinese characteristics in the new era from the interpretation of the global thoughts of the Communist Manifesto. At present, the academic world has studied the globalization of thoughts in the Manifesto of the Communist Party (hereinafter referred to as the Manifesto), and has experienced a shift from economy to politics to culture. Among them, the research on the thought of cultural globalization can continue.

\section{Cultural GlobaliZATION IN THE MANIFESTO}

When talking about the issue of "historical transformation into world history", Marx and Engels stated that the closed, conservative and self-sufficient situation of all ethnic groups in the past has been broken, and interaction and interdependence have become normal. "So is material production, so is spiritual production." They then pointed out that with the process of globalization; all ethnic groups have established their own modern industrial production methods and lifestyles corresponding to their production methods. At the same time, consumption patterns have also become more and more consistent, prompting many similar cultural concepts to form between different countries. This has laid an internal foundation for cultural exchanges between different countries. The universal exchanges required by modern big industries, such as the development of information communication and transportation, have created opportunities and conditions for cultural dissemination and exchanges, thus opening up a new era of cultural globalization. "Cultural globalization" refers to the communication, penetration, identification, and sharing of national cultures across a range of obstacles, including regional space and social systems. As a result, the trend and process of "global culture" was formed. Its connotation mainly includes two layers: 1. Cultural globalization is a process that emphasizes the increasingly close exchanges, conflicts and integration of cultures between countries, thereby increasing cultural commonality. 2. On the basis of the gradual expansion of cultural commonality, nations and countries continue to transcend narrow national and local boundaries, and eventually form a more integrated "global culture" trend. "Manifesto" emphasizes: "The spiritual products of various nations have become public property. The one-sidedness and limitations of nations have become increasingly impossible, so many kinds of national and local literature have formed a world literature. The "world literature" mentioned here refers to the highly integrated global culture, which reflects the ideals and beliefs of the people of the world, and is applicable to the "culture in 
general" among all nations and countries in the world. On the contrary, "global culture" does not mean that it represents a single culture, nor does it mean that national culture will disappear. It simply eliminates the narrow national culture. The national culture originates from the different material production methods of each nation and the complex and diverse human and geographical environment of each nation. Although the process of globalization has brought the production methods of all nationalities into convergence, it has also shown various variations due to the influence of racial genes, the natural environment, and empirical facts. Therefore, the convergence between cultures is only reflected in the nature level, and the content and forms that reflect the nature of culture are diverse. Cultural globalization is the "unification of diversity" in the highly integrated form of national cultures.

Cultural globalization uses capitalist cultural expansion to pave the way for itself. There are two reasons:

First, the culture of western capitalist countries that established modern culture has adapted to modern material production methods. These cultures containing advanced factors have strong communication power and permeability. For countries that are in the process of modernization, in order to promote cultural modernization, they must absorb the essence of the culture of developed countries, which has caused capitalist culture to be closely related to cultural globalization.

Secondly, from the origin of globalization and its development stage, capitalist production mode takes global expansion as a symbol of globalization, and constitutes a global development pattern dominated by capital. Developed countries, while exporting capital, information, and commodities to developing countries, are also exporting culture to achieve the intent to assimilate or dissolve the cultures of other countries, thereby maintaining their absolute advantages in the process of globalization. Although cultural globalization was first initiated by advanced capitalist culture, it is ultimately difficult to achieve a "global culture" in which all nations coexist equally. Because the capitalist culture has disadvantages: people are in opposition to themselves, society and nature, and they are constantly alienating, and the cultural development of various ethnic groups is uneven, and conflicts are escalating. Only socialist culture, as a transcendence of capitalist culture, can truly realize the "global culture".

\section{Problems of ChinA's Cultural CONFIDENCE Since MODERN TIMES}

Marx pointed out that "the essence of human is not an abstract of a single person; in its reality, it is the sum of all social relations" [3]. The essence of "ego" is always confirmed and realized in comparison with "alter ego". National culture often realizes self-understanding and development in the interaction and reflection of heterogeneous culture. Since the Industrial Revolution, capitalist production has completed the transition from factory handicrafts to large-scale industrial production. Productivity has increased tremendously, commodity output has been increasing, and the desire to expand markets and find sales has become stronger. The opening of new routes provides possibilities for trade exchanges between countries, driven by benefits and increasingly developed modes of transportation, and has created conditions for the global movement, development and settlement of the bourgeoisie. In contrast to China at that time, due to the lack of the baptism of the Industrial Revolution, capitalism was not fully developed, and farming civilization still dominated. The seclusion of the country for a long time has immersed the Chinese in the beautiful fantasy of Celestial Empire. It is the cannon guns and cheap goods that pry open China's door and destroy the Chinese dream. Successive defeats in the war and inequality treaties that have been signed have caused China, which has always been highly regarded, to suffer. The ancient Chinese civilization, once proud of it, was mercilessly martyred, and all kinds of backwardness became the gloom hanging over the Chinese people. Liang Qichao wrote in "Introduction to the Evolution of China in Fifty Years": "The Chinese first felt inadequate from the utensils, then from the system, and then from the cultural perspective" [4]. From utensils to institutions to culture, this cognitive process vividly describes the changes in the mentality of the people abroad. Since the Opium War, repeated defeats and traumas have caused China to be negative by the "other" externally, and in the comparison, it has also rejected "self". Accompanying the depression of national fate is the loss of culture, the lack of value, and the sluggishness of thought. The situation of strong enemies and weak ones made "the introduction of western learning to the east" a popular trend of thought at the time. People of insight put forward different plans from the aspects of utensils, systems, and culture. For example, "practical" ideas with the concept of "learn from foreigners to compete with them", westernization movement with "westernized Chinese style" as the theoretical core, ideological trend of reformation with "save the nation from extinction" as the goal, and the revolutionary ideology of "democracy, freedom, equality" and the new civilization movement centered on "democracy" and "science", etc. However, the above-mentioned solutions have not allowed China, which has already withered, to come out of its difficulties. On the contrary, the failures again and again exacerbate the Chinese people's suspicion of their own culture and the fear of Western culture, even xenocentric. How to make the lost Chinese culture regain confidence and rebuild the Chinese value that is out of the norm? A new opportunity came to the fore, and this was the introduction of Marxism and the birth of the Chinese Communist Party. Comrade Mao Zedong pointed out: "Compared with the old feudal culture of China, the western bourgeois culture that can be regarded as" highly cultural "by the Achesons, once met the new MarxistLeninist culture learned by the Chinese people, that is, the scientific view of the universe and the theory of social revolution, is about to lost the battle "[5]. Looking back on the development of the Communist Party of China, it can be seen that the road China has taken is neither "westernized Chinese style" nor "west painting by the Chinese painting skill", neither "reviving Confucianism" nor "wholesale westernization", but a road combining the scientific principles of Marxism with China's outstanding traditional culture and China's specific national conditions. The scientific nature of this path is that it can allow Marxism, which represents 
advanced ideas, to speak "Chinese," and allow ancient Chinese culture to speak "modern words".

\section{THE IMPORTANCE OF CULTURAL CONFIDENCE IN} SOCIALISM WITH CHINESE CHARACTERISTICS IN THE NEW ERA

In today's world, the trend of culture is undergoing the process from regionalization to globalization, from discrete space-time to synchronous space-time. The game between nations has become more covert than before, gradually shifting from rigid "hard power" confrontations such as economy, territory, and military to flexible "soft power" contests such as culture and values. In this international context, the cultural strategic position has become more prominent, and it has increasingly become an important sector and key area for comprehensive national power competition. "Cultural confidence" was put forward on the basis of accurate research and deep understanding of world conditions, national conditions, party conditions, and modern history, and has great era value.

First, cultural confidence is related to the prosperity and decline of the national fate. Cultural fate and national fate appreciate each other, and cultural fate is connected with national fate. Culture is not only a reflection of the political and economic conditions of a given society on ideology, but it can also actively affect political and economic development. Looking back on history, the prosperity of each country is all supported by the prosperity of culture, and the prosperity of each era is based on the prosperity of culture. General Secretary Xi Jinping pointed out, "Without the inheritance and development of civilization, and without the promotion and prosperity of culture, there will be no realization of the Chinese dream" [6]. The cultural confidence that has grown out of rich historical and cultural resources and outstanding socialist cultural practices provides important value guidance and spiritual support for the realization of the Chinese dream of the great rejuvenation of the Chinese nation. It is the basis for reaching value consensus and clear value ideals. At the same time, cultural confidence is also an inevitable requirement for cultural innovation and transmission of Chinese values.

Second, cultural confidence is about cultural security. Cultural confidence is a high recognition and conscious practice of the cultural value of a nation, and is the ideological basis for maintaining national cultural security. First, cultural confidence is the ideological weapon for dealing with ideological struggles. Ideological issues are about flags, systems, and roads. Only the cultural confidence based on common cultural heritage, cultural values, and cultural beliefs can hold the ground and have the initiative in the increasingly fierce ideological struggle. Second, cultural confidence is the value foundation to resist the impact of bad cultural thoughts. The advancement of globalization and the development of science and technology have made country-to-country exchanges and people-to-people exchanges more convenient, but at the same time, they have also facilitated the entry, breeding, and spread of bad ideas. This requires people to have a high degree of cultural confidence, to rationally examine their own culture, and to look at foreign cultures. People do not blindly reject the advanced culture of other countries, nor do they dwarf their own national culture, and realize cultural exchanges and mutual learning in screening.

Finally, cultural confidence is related to national spiritual independence. National spiritual independence is the foundation of a state and a nation. History and reality have shown that states and nations that abandon or betray the national spiritual independence will not only develop, but will instead become vassals of ideology and affiliations of reality in other countries. Therefore, maintaining national spirit independence and upholding its own value stand is about national origin. On the one hand, cultural confidence provides a deep cultural foundation for the independence of the national spirit. The outstanding traditional culture accumulated over the past five thousand years reflects the unique spiritual genes of the Chinese nation that distinguish it from people. It is this unique spiritual gene that inherently determines the independence of the Chinese nation's spirit. On the other hand, cultural confidence provides clear guidelines for national spiritual independence. The essence of cultural confidence is confidence in the core values of socialism with Chinese characteristics. This value is based on China's unique historical and cultural background and unique cultural development path, which reflects Chinese values, Chinese standards, and Chinese confidence.

V. THE OPPORTUNITIES, CHALLENGES, AND

ENLIGHTENMENTS BROUGHT BY CULTURAL GLOBALIZATION TO THE CULTURAL CONFIDENCE OF ADHERING TO THE SOCIALISM WITH CHINESE CHARACTERISTICS

\section{A. Opportunities and Challenges}

On the one hand, based on the development of cultural globalization, human culture can transcend the limits of national borders, and various cultural elements can be spread and exchanged globally. This builds a bridge for national culture to learn from the excellent achievements of other civilizations, so that national culture can accelerate the pace of development. On the other hand, cultural globalization also has a negative effect on the development of national culture. Today, the cultural life of various countries is still in an unfair order. A few western countries occupy the commanding heights, and cultural imperialism and hegemonism still exist. While national culture actively enters the ranks of cultural globalization and enjoys the benefits, it is also facing many severe tests.

\section{B. Enlightenment}

1) Active intergration of cultural globalization: With the acceleration of economic globalization, cultural globalization is permeating everywhere. The bourgeoisie has brought "all nations and even the most barbaric nations into civilization." Cultural exchanges between various ethnic groups have deepened, and cultural boundaries between regions have become increasingly blurred. "National common culture" is becoming more prominent and even converging. This is a cultural development trend that no country or nation can evade. Therefore, as for the world culture and nationality, people should not conquer, reject and xenophobic crudely, or 
simply transplant them. Instead, they should integrate, absorb and innovate.

The construction of a socialist culture with Chinese characteristics in the new era requires a good inheritance and bold innovation of the Chinese nation, so that the Chinese nation culture can actively respond to the needs of economic and political development in the new stage, and can be loved by people in other countries. This is the basis and prerequisite for China's move towards cultural globalization. At the same time, Chinese culture, which is in the process of cultural globalization, must not stand still and must go abroad steadfastly and take the initiative to communicate with other countries. During going abroad, Chinese culture must take the initiative to absorb and digest all the outstanding cultural achievements of other countries and realize "make foreign things serve china". Mao Zedong pointed out in this regard that foreign advanced culture should be absorbed as the "raw material of food" of Chinese culture. He will learn the analogy of foreign cultures to the process of chewing food for humans. After oral and gastrointestinal movements, "feed the salivary gastric juice and intestinal fluid, break it into two parts, the essence and the dregs, and then excrete the dregs and absorb the essence."

2) Cultural globalization requires inheritance and innovation of the nation's outstanding traditional culture: The foresight of cultural globalization in Manifesto is not intended to obliterate the cultural identity of various peoples. What it emphasizes is "the unity of diversity", which is the symbiosis and prosperity of different regional cultures in the world. Just as the diversity of species in nature can make ecological balance, so is the development of world culture. National culture and world culture are mutually reinforcing and parallel.

Chinese excellent traditional culture is the unique cultural resource of the Chinese nation, the spiritual root of the Chinese nation, and the fertile ground for the formation and development of cultural confidence. Marx pointed out: "People create their own history. But they do not create it at will, not under conditions of their own choice, but under conditions that they have encountered directly, are established and inherited from the past "[7] China's outstanding traditional culture is undoubtedly the foundation of socialist cultural development. Mao Zedong said, "China's current new politics and new economy have developed from ancient old politics and old economy, and China's current new culture has also developed from ancient old culture. Therefore, people must respect their own history and history can't be cut off "[8]. This also further discusses the significance of China's excellent traditional culture.

3) Promoting ideological education and maintaining national cultural security: At present, the CCP's key work is to use Marxism as a firm guide to improve ideological education and resist its diversity and chaos. The socialist core values and socialist core value system proposed by China are the core of the socialist system and its ideology, and the soul of life of the various ideological cultures and values of the Chinese nation, leading the development of socialist culture with Chinese characteristics.
The core values of socialism, as the condensed expression of the core value system of socialism with Chinese characteristics, are formed on the basis of absorbing the fruits of human civilization and the fruits of socialist practice, were formed under the confrontation of values in global cultural exchanges, were formed in the face of new characteristics of diversified ideology in the new situation. They are the value propositions and value orientations that have the greatest common denominator to help realize the Chinese dream of the great rejuvenation of the Chinese nation, to achieve all-round human development and lead the all-round progress of society. In the current international environment of ideological confrontation, actively cultivating and fulfilling the core values of socialism is conducive to consolidating the guiding position of Marxism in the ideological field and continually strengthening the road, theory, and system of socialism with Chinese characteristics, and has important theoretical and practical significance for the practice of socialism with Chinese characteristics.

\section{CONCLUSION}

Today, China faces many cultural difficulties. For example, people's limited knowledge of traditional culture, the infiltration of various foreign thoughts, the lack of morality in some areas, the distorted outlook on life, values, and the world view of some people. Therefore, people urgently need to implement ideological education and always take the socialist core value system as the lead. It is necessary to adopt the dialectical thinking of Marxist philosophy, so that the entire population respects cultural differences and diversity, and establishes a conscious cultural belief, so as to effectively get rid of the errors and the corrosion of backward thoughts.

From a dialectical, concrete, and historical perspective, cultural creativity should be based on absorbing the beneficial elements of all civilizations created by human society in the past, and let the outstanding cultural genes release the energy of modernization. Cultural creativity should fully draw on the beneficial cultural achievements created by all civilizations, actively discover new situations and changes, and extensively absorb new ideas, new perspectives, new knowledge and new technologies, so that advanced cultural development achievements can be used by themselves. This is the proper meaning of cultural globalization.

\section{REFERENCES}

[1] Xi Jinping. Determining the victory of building a well-off society in an all-round way and seizing the great victory of socialism with Chinese characteristics in the new era - Report at the 19th National Congress of the Communist Party of China [M]. Beijing: People's Publishing House. 2017. (in Chinese)

[2] Same as [1]

[3] Anthology of Marx and Engels, Volume 1 [M]. Beijing: People's Publishing House. 2012. (in Chinese)

[4] Liang Qichao. An Introduction to Chinese Evolution in Fifty Years [M]. Beijing: Beijing Publishing House. 1999. (in Chinese)

[5] Selected Works of Mao Zedong, Volume 4 [M]. Beijing: People's Publishing House. 1991. (in Chinese) 
[6] Xi Jinping. Speech at UNESCO Headquarters (in Chinese) [EB/OL]. http://www.xinhuanet.com//politics/2014-

03/28/c_119982831.htm. March 27, 2014.

[7] Karl Marx and Frederick Engels, Volume 8 [M]. Beijing: People's Publishing House. 1961. (in Chinese)

[8] Selected Works of Mao Zedong, Volume II [M]. Beijing: People's Publishing House. 1991. (in Chinese) 